\title{
EARLY SPRING FLOWERING IN NOVA SCOTIA: AN EXTREME SPRING IS REFLECTED IN ADVANCED FLOWERING
}

\author{
NICHOLAS M. HILL ${ }^{1}$, DAVID J. GARBARY2* \\ ${ }^{1}$ Fern Hill Institute of Plant Conservation \\ Bentley Rd., South Berwick, Nova Scotia \\ ${ }^{2}$ Department of Biology, St. Francis Xavier University \\ Antigonish, Nova Scotia, B2G 2W5
}

\begin{abstract}
Twenty species of herbaceous plants and four non-amentiferous shrubs were found in flower in March-April in Nova Scotia during the spring of 2012. Plants were observed primarily in Kings and Antigonish Counties, with several observations from Inverness County. The precocious flowering is attributed to an abnormally warm late winter and spring (FebruaryMarch) in which climate normals for monthly average temperature were exceeded by a minimum of $1.2^{\circ} \mathrm{C}$ in February (Tracadie) to a maximum of $8.5^{\circ} \mathrm{C}$ in March (Kentville). Flowering was an average of 17 days earlier than herbarium records in the largest regional herbaria (ACAD, NSAC). Proportional contribution to the early flowering guild was greater for exotic species which featured weedy families not represented in the native group. These observations of spring climate conditions and flowering phenology are consistent with regional climate change associated with milder and earlier springs.

Key Words: climate change, Nova Scotia, phenology, spring flowering, exotic range expansion.
\end{abstract}

\section{INTRODUCTION}

Global climate change over the course of the $20^{\text {th }}$ century is well established. It is generally recognized that mean air temperature has increased $0.5-0.6^{\circ} \mathrm{C}$ and that biological systems have responded accordingly (e.g., Houghton et al. 2001, McCarty 2001, Menzel et al. 2005, Walther et al. 2005, Core Writing Team IPCC 2007). Biological responses to global climate change have often been associated with changes in migration timing, distribution of organisms with regard to

Authors to whom correspondence should be addressed:

fernhillns@gmail.com or dgarbary@gmail.com 
elevation, changes in animal breeding times, and various aspects of plant phenology: timing of leaf bud burst, onset of leaf colour change and flowering phenology. Menzel (2003) argued that aspects of plant phenology provided an excellent proxy for temperature, and there is an extensive literature on advancement of flowering times in relation to climate change (e.g., Abu-Asab et al. 2001, Fitter and Fitter 2002, Gu et al. 2008, Houle 2007, Miller-Rushing \& Primack 2008, Panchen et al. 2012).

Herbarium records of flowering phenology in Nova Scotia during the $20^{\text {th }}$ century are concentrated between May and October, with a few stragglers in either spring or fall (Roland 1998). In Nova Scotia, responses of plants to changing temperature regimes have emphasized late fall flowering in which extensive flowering after November 1 has been documented. Thus, in the years following 2000 there have been two years when over 90 and 130 species flowered after November 1, and flowering continued into December and January in 2001 and 2006, respectively (Garbary and Taylor 2007, Garbary et al. 2012, Taylor and Garbary 2003). The highlight of these accounts was the occurrence of 20 species flowering in January, with the last day being January 21. The demonstration of advancement of spring flowering in Nova Scotia has been more problematic. Despite a well-documented increase in spring temperatures over the $20^{\text {th }}$ century, Vasseur et al. (2001) were able to demonstrate limited advance in flowering that was associated with only a single cultivated shrub, Syringa vulgaris.

In this paper we demonstrate that temperatures for the late winter and spring of 2012 in Nova Scotia were considerably elevated relative to climate normals (Kings Co.) or for the previous nine years (Antigonish Co.). We then provide observations of flowering of 24 species during March and April, and compare the resulting phenology with the earliest flowering records in regional herbaria.

Given the record setting temperatures in mid March, we ask whether or not plants responded by coming into flower earlier than normal. We evaluate the resulting phenology in the context of potential impact of regional climate change.

\section{METHODS}

The burst of abnormal temperatures in mid-March prompted us to examine the potential response of flowering in two areas of the province: Kings County in the Annapolis Valley (NH) and Antigonish 
County in northern Nova Scotia (DG). Habitats included agricultural fields and orchards, disturbed ground and building lots and natural forest communities. We avoided heat islands associated with urban developments such as garden plots immediately adjacent to buildings or at the base of walls. Records of flowering were compared with accounts in Roland (1998), records from herbaria at Acadia University (ACAD), Nova Scotia Agricultural College (NSAC) and St. Francis Xavier University Herbarium (STFX). An online database associated with the E.C.Smith herbarium (i.e, ACAD, http://herbarium.acadiau. ca) also includes records from Cape Breton University Herbarium. We avoided the catkin producing genera (i.e. Alnus, Populus and Salix) as they may be regarded as winter flowering, and many began flowering before our observations commenced. We also did not include trees (e.g., Acer spp.).

Climate data for Nova Scotia were obtained from the internet (http://www.climate.weatheroffice.gc.ca/Welcome_e.html). Kentville $\left(45^{\circ} 04^{\prime} \mathrm{N}, 64^{\circ} 29^{\prime} \mathrm{W}\right.$, Kings Co.) was used as the reference site for South Berwick $\left(45^{\circ} 1.4^{\prime} \mathrm{N}, 64^{\circ} 42.6^{\prime} \mathrm{W}\right)$ where most of the observations were made by $\mathrm{NMH}$. Tracadie $\left(45^{\circ} 36^{\prime} \mathrm{N}, 61^{\circ} 40^{\prime} \mathrm{W}\right.$, Antigonish Co.) was used as the reference site for Antigonish town and environs $\left(45^{\circ} 37.4 \mathrm{~N}, 61^{\circ} 59.5^{\prime} \mathrm{W}\right)$ where most of the observations were made by DJG. The Tracadie weather station has only been operating since 2003, and 'climate normals' were calculated based on data averaged from 2003-2011. Data for snowpack at the end of each month were only available for Kentville.

\section{RESULTS}

\section{Climate}

As shown by the climate normals, February through April are not particularly conducive to plant growth and flowering in Nova Scotia (Table 1). There is typically extensive snowfall, and considerable snowpack remaining at the end of each month. While the data for Antigonish Co. are not available, the lower temperatures would suggest even greater snowpack than for the Annapolis Valley. The mild winter of 2012 was characterized by an $88 \%$ reduction in snowpack at the end of February and 100\% reduction in March and April.

The relative absence of snow was reflected in the differences in temperature regimes between climate normals and 2012 (Table 1, 
Table 1 Climate normals for Kentville (Kings Co., Annapolis Valley, 1971-2000), and Tracadie (Antigonish Co., 2003-2011), and weather regimes during February-April 2012.

\begin{tabular}{lcccrrr}
\hline Climate normals & February & $\begin{array}{c}\text { Kentville } \\
\text { March }\end{array}$ & April & February & $\begin{array}{c}\text { Tracadie } \\
\text { March }\end{array}$ & April \\
\hline Daily average $\left({ }^{\circ} \mathrm{C}\right)$ & -5.2 & -0.9 & 4.9 & -5.0 & -2.1 & 4.1 \\
Daily maximum $\left({ }^{\circ} \mathrm{C}\right)$ & -0.9 & 3.4 & 9.5 & 7.8 & 2.1 & 8.3 \\
Daily minimum $\left({ }^{\circ} \mathrm{C}\right)$ & -9.5 & -5.2 & 0.4 & -19.6 & -14.2 & -5.1 \\
Degree days $>5^{\circ} \mathrm{C}$ & 1.8 & 8.7 & 46.1 & 0.2 & 4.3 & 33.4 \\
Snow on ground at & & & & & & \\
$\quad$ month end $(\mathrm{cm})$ & 59 & 46 & 17.3 & - & - & - \\
$\quad$ Weather 2012 & & & & & & \\
Daily average $\left({ }^{\circ} \mathrm{C}\right)$ & -3.5 & 7.6 & 12.6 & -3.8 & 5.2 & 10.4 \\
Maximum $\left({ }^{\circ} \mathrm{C}\right)$ & 7.3 & 25.7 & 23.0 & 9.7 & 25.4 & 19.8 \\
Minimum $\left({ }^{\circ} \mathrm{C}\right)$ & -15.8 & -11.4 & -4.8 & -18.6 & -11.5 & -6.1 \\
Degree days $>5^{\circ} \mathrm{C}$ & 0 & 41.2 & 78.8 & 0.6 & 28.8 & 74.6 \\
Snow on ground at & & & & & & \\
$\quad$ month end $(\mathrm{cm})$ & 7 & 0 & 0 & - & - & - \\
\hline
\end{tabular}

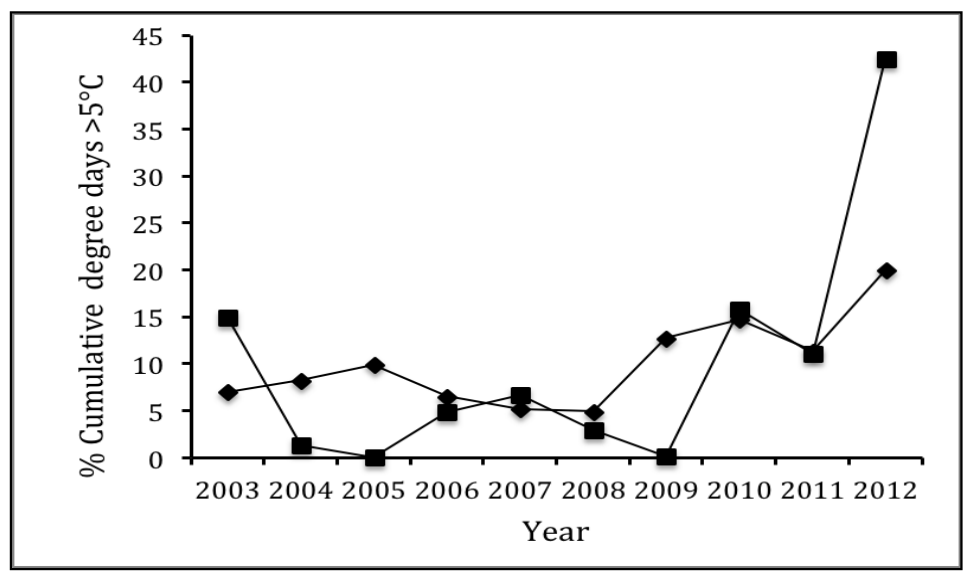

Fig 1 Percent contribution to decadal total of cumulative degree days $>5^{\circ} \mathrm{C}$ for each of the individual years (2003 to 2012) for March (boxes) and April (diamonds).

Fig. 1). In both of the primary areas, climate normals showed daily averages below zero for February and March, and below $5^{\circ} \mathrm{C}$ for April (Table 1). The daily average temperature was $1.7^{\circ} \mathrm{C}$ and $1.2^{\circ} \mathrm{C}$ warmer for February relative to climate normals in the two areas, and these differences became more extreme in March and April. For Kentville, daily average temperatures were $8.5^{\circ} \mathrm{C}$ and $7.7^{\circ} \mathrm{C}$ warmer than normal for March and April, and the equivalent values for Tracadie were $7.3^{\circ} \mathrm{C}$ 
and $6.3^{\circ} \mathrm{C}$. Average daily maximum temperatures for climate normals did not exceed $10^{\circ} \mathrm{C}$ and extreme minima were $-14.2^{\circ} \mathrm{C}$ and -5.1 for March and April, respectively. During spring, degree days $>5^{\circ} \mathrm{C}$ are normally limited in Nova Scotia, with values of 4.3 and 8.7 (March) and 33.4 and 46.1 (April) for the two areas. Degree days $>5^{\circ} \mathrm{C}$ are shown for Tracadie from 2003-12 (Fig 1), and the values for 2012 are extreme relative to previous years, with a 2.2 to 6.7 fold increase relative to means of the previous nine years, and a $30 \%$ to over $200 \%$ increase relative to previous maximum values.

\section{Plant Phenology}

Observations made of first flowering times for 24 plant species were compared with the first flowering records found among the collections in the E.C. Smith (ACAD) and Roland (NSAC) Herbaria (Table 2). On the one hand, since all of these records were based on opportunistic sampling across a wide geographic area (northern Cape Breton to the Annapolis Valley), we do not claim that the dates represent first flowering of the species. However, our observations are likely very close to first flowering in the following species: 1) Draba verna and Daphne mezerium from Antigonish where the sites were visited every few days until anthesis; 2) Senecio vulgaris from Antigonish where a single individual had only a few blossoms; and 3) Tussilago farfara where only a single site had a few flowers, when other populations were still in bud. On the other hand, many individuals of Caltha palustris were in flower in roadside wetlands around Cheticamp, suggesting that it had been in blossom for at least several days. In all but four species, first flowering was earlier in 2012 than for the herbarium specimens, a record spanning more than a century. Overall, flowering was $17.5 \pm$ 17.4 days earlier than the earliest records in the herbaria. One of the species for which we did not claim an earlier record was for Taraxacum officinale for which the record comes from Sable Island with the habitat "west side of meteorological station" (ACAD \#31833). We did not include observations of this species from equivalent heat islands in Antigonish where plants were in flower by April 1.

Five species were observed in both the Annapolis Valley and Antigonish Co. during March and April. In every case the Annapolis Valley observations were earlier, and the difference ranged from 2-20 days (mean of $10 \mathrm{~d}$ ). At least four additional conspicuous species had not come into flower in Antigonish Co. that would have been documented if they had flowered. 
Table 2 List of species collected and dates of collection in Annapolis Valley (Kings County) and Antigonish and Inverness Counties in 2012 with earliest previous collections based on records at E.C. Smith Herbarium (ACAD) and the A.E. Roland Herbarium (NSAC). Abbreviations: N- native, E- exotic, NO- not observed.

\begin{tabular}{|c|c|c|c|c|c|}
\hline Species & $\begin{array}{l}\text { Origin } \\
\text { (native or } \\
\text { exotic) }\end{array}$ & $\begin{array}{c}\text { Collection } \\
\text { date }\end{array}$ & & $\begin{array}{l}\text { Earliest Nova } \\
\text { cotia record in } \\
\text { ACAD } \\
\text { or NSAC }\end{array}$ & $\begin{array}{l}\text { \# days of } \\
\text { advanced } \\
\text { flowering }\end{array}$ \\
\hline & & $\begin{array}{l}\text { Annapolis } \\
\text { Valley }\end{array}$ & $\begin{array}{l}\text { Antigonish } \\
\text { and } \\
\text { nverness Co. }\end{array}$ & & \\
\hline Amelanchier laevis Wieg. & $\mathrm{N}$ & Apr 25 & NO & Apr 8, 1938 & -17 \\
\hline $\begin{array}{l}\text { Caltha palustris } \mathrm{L} . \\
\text { Capsella bursa- }\end{array}$ & $\mathrm{N}$ & Absent & April 27 & May 24, 1999 & 27 \\
\hline pastoris (L.) Medikus & $\mathrm{E}$ & Mar 24 & NO & Mar. 28, 1910 & 4 \\
\hline $\begin{array}{l}\text { Cerastium vulgatum } \mathrm{L} . \\
\text { Clavtonia caroliniana }\end{array}$ & $\mathrm{E}$ & NO & April 18 & May 24, 1979 & 36 \\
\hline Michx. & $\mathrm{N}$ & NO & April 29 & May 1,1948 & 2 \\
\hline Corylus cornuta Marshall & $\mathrm{N}$ & Mar 25 & NO & Apr 25,1928 & 31 \\
\hline Daphne mezerium $\mathrm{L}$. & $\mathrm{E}$ & Mar 25 & April 8 & Apr 10, 1920 & 16 \\
\hline Draba verna $\mathrm{L}$. & $\mathrm{E}$ & Mar 17 & April 6 & Apr 14, 2002 & 28 \\
\hline Epigea repens $\mathrm{L}$. & $\mathrm{N}$ & NO & April 15 & Apr 20, 1928 & 5 \\
\hline Fragaria virginiana & & & & & \\
\hline Duchesne & $\mathrm{N}$ & Apr 16 & April 28 & Apr 25, 1998 & 9 \\
\hline $\begin{array}{l}\text { Glechoma hederaceae L. } \\
\text { Hedyotis caerulea }(\mathrm{L} .)\end{array}$ & $\mathrm{E}$ & NO & April 18 & May 8, 1936 & 20 \\
\hline Hook. & $\mathrm{N}$ & Apr 20 & NO & May 10,1980 & 20 \\
\hline Lonicera canadensis Bartr. & $\mathrm{N}$ & Apr 20 & April 29 & May 1, 1997 & 2 \\
\hline Myosotis scorpioides L. & $\mathrm{E}$ & NO & April 29 & May 14,1980 & 15 \\
\hline Sanguinaria canadensis L. & $\mathrm{N}$ & Apr 18 & April 20 & May 17,1952 & 29 \\
\hline $\begin{array}{l}\text { Senecio vulgaris } \mathrm{L} . \\
\text { Stellaria media (L.) }\end{array}$ & $\mathrm{E}$ & Not & April 15 & June 16,2001 & 62 \\
\hline Cyrillo & E & Mar 28 & NO & Apr 20, 2002 & 23 \\
\hline Taraxacum officinale $\mathrm{L}$. & E & $\mathrm{NO}$ & April 26 & Apr 25, 1953 & -1 \\
\hline Tussilago farfara $\mathrm{L}$. & E & $\mathrm{NO}$ & March 20 & Apr 25,1995 & 36 \\
\hline Vinca minor L. & E & Apr 15 & NO & May 20, 1949 & 35 \\
\hline Viola cucullata Ait. & $\mathrm{N}$ & Apr 30 & NO & Apr 30, 1980 & 0 \\
\hline Viola macloskeyi Lloyd & $\mathrm{N}$ & Apr 30 & NO & Apr 23, 1980 & -7 \\
\hline Viola pubescens Ait. & $\mathrm{N}$ & Apr 30 & NO & May 26, 1977 & 26 \\
\hline Viola tricolor $\mathrm{L}$. & E & NO & April 26 & May 16, 2002 & 20 \\
\hline
\end{tabular}

\section{DISCUSSION}

Atypical temperatures for one spring are not indicators of climate change, though they may be useful for indicating how communities may shift with the elevated temperatures of climate change. Spring of 2012 was exceptionally warm over much of North America, and March and April in Nova Scotia broke records. Temperatures in excess 
of $25^{\circ} \mathrm{C}$ were recorded for several days in March and this atypical warmth followed a particularly mild winter with relatively little snowfall (Table 1). Subsequent spring weather in April was also above normal, although to a lesser extent than March.

How different members in a plant community respond to such a pulse of increased temperature may well reflect the inherent plasticity of different species. This in turn may be an indicator of performance over the next century when temperatures in temperate regions are projected to increase by a further $2^{\circ} \mathrm{C}$.

Our scope was narrow: we set out to record the first species to flower in 2012 and to compare these flowering dates to historical data of flowering in local herbaria. It has been documented that flowering is occurring at earlier times of year in recent years than in the past, and Miller-Rushing and Primack (2008) have used historical data at Walden Pond, MA, to demonstrate this. Flowering onset in the temperate region is determined mainly by temperature (Miller-Rushing and Primack 2008); soil moisture levels and precipitation do not appear to be limiting factors in most years. Panchen et al. (2012) used a combination of herbarium records, photographs and naturalists' notes to document earlier flowering over the last century around Philadelphia. While we only formally consulted herbarium records, our informal observations over the last 20 years are congruent with the unusual phenology observed in 2012. Another botanical indicator of an early spring in Antigonish Co. included a harvest of Matteucia struthiopteris (L.) Todaro on April 29; this predates the earliest previous harvest from the last 25 years of May 10 (Dolna Garbary, personal communication). Several additional species of spring wildflowers showed expanded bud development at the end of April (Panax trifolius L., Erythronium americanum Ker-Gawler, Clintonia boreale (Aiton) Raf., Maianthemum canadense Desf.); however, we were unable to return to the site to observe anthesis of these species.

Recent weather extremes in late fall and early winter were associated with late fall flowering in 2000 when flowering terminated in mid December (Taylor and Garbary 2003) and in 2005-2006 when flowering extended until 21 January (Garbary et al. 2012, Garbary and Taylor 2007). While there is realistically a two-month gap between the dates of extreme late flowering in 2006 and the extreme early flowering in 2012, these records suggest that with a repeat of the late fall-early winter conditions of 2005-2006, accompanied by an early spring (i.e., as in 2012), we would anticipate flowering in 11 months of the year. 
Vasseur et al. (2001) examined long-term records of spring phenology in selected plants in Nova Scotia using historical records between 1892 and 1923 and more recent observations from 1998 based on Nova Scotia Plantwatch. Only one species, Syringa vulgaris, showed significant flowering at an earlier date. Vasseur et al. (2001) used their analysis to point out the earlier flowering in the southern and western parts of Nova Scotia relative to the northern and eastern portions where there is a harsher climate zone (zone 5 versus 6). This change in climate zones is consistent with our observations on nine species. Regardless of the fact that the warm March weather was apparent in most of the province, flowering in Antigonish was about 10 days later.

Native and exotic taxa were equally represented among the 24 early flowering species. Since exotic species are a minority of the total flora, a weighted analysis was required. Exotics account for more than a third of the flora in Nova Scotia (Hill and Blaney 2010) but even this overestimates their real frequency, since many of these exotics are transitory and fail to become established in the regional flora. When a Chi-square analysis is performed using only the common native and exotic species, (i.e., subtracting the rare and transient species from both groups), exotic species are significantly $(\mathrm{p}<0.05)$ overrepresented in the early spring flowering guild. In addition to a greater proportional representation of exotics among the early flowering plants, their seasonal shift in flowering time, from the earliest records in herbaria, was significantly earlier than that of native plants (see Table 2). The average shift in flowering time was two weeks earlier for the group of exotic plants than the natives (2012 flowering time shifts $=24.5$ \pm 16.7 versus $10.6 \pm 15.7$ days for exotics and natives respectively). Many of the exotic species are ruderals, plants adapted to frequently disturbed habitats through fast growth rate and early and often lethal reproduction (Grime 1979). The evolution of this set of ruderal traits is pronounced in several highly successful families which are also those best represented among the world's worst weeds (Huston 1994). Early flowering exotic representatives in Nova Scotia were with one exception all short-lived herbs representing three of the top weedy families ( 3 species of Asteraceae, 2 Brassicaceae, and 1 Lamiaceae) that contribute 10 or more species to the World's Worst Weeds (Holm et al. 1979, cited in Huston 1994). Although herbs were best represented among the early flowering native plants, this group shared only one family with the exotics (Violaceae) and it represented only one of the common weedy families (viz. the Rosaceae, 2 represented in native 
groups). Based on the above differences in their relative contribution to the early flowering records, their 2012 flowering shift, and their phylogenetic origins, these exotics are clearly the group poised to expand, given a fundamental change in spring climate.

Our observations provide the earliest flowering records of over 20 species based on herbarium records, and these records average 17 days earlier than the earliest of these specimens. While it is tempting to conclude that we have shown an advancement of 17 days in average flowering, such a conclusion is moderated by the fact that our records are based on haphazard observations in 2012 rather than systematic observations over many years. Furthermore, it is unlikely that previous herbarium specimens were collected to demonstrate earliest flowering times. Regardless, our observations provide a baseline in two areas of Nova Scotia for first flowering times for some conspicuous wildflowers. The congruence of record spring temperatures (Table 1, Fig. 1) along with the flowering phenology (Table 2) suggests that flowering was indeed advanced for these species.

Acknowledgements We thank Chelsea Fougere for information on flowering of coltsfoot and the Curators of ACAD and NSAC for access to herbaria. This work was supported by grants from the Natural Sciences and Engineering Research Council of Canada to D.G.

\section{REFERENCES}

Abu-Asab, M.S., Peterson, P.M., Shetle, S.G., \& Orli, S.S. (2001) Earlier plant flowering in spring as a response to global warming in the Washington, DC, area. Biodiversity and Bioconservation 10: 597-612.

Core Writing Team, Pachauri, R.K., \& Reisinger, A. (Editors) (2007) IPCC. Climate Change 2007: Synthesis Report. Contribution of Working Groups I, II and III to the Fourth Assessment Report of the Intergovernmental Panel on Climate Change. IPCC, Geneva, Switzerland.

Fitter, A.H., \& Fitter, R.S.R. (2002) Rapid changes in flowering time in British plants. Science 296: 1689-1691.

Garbary, D.J., Ferrier, J., \& Taylor, B.R. (2012) Late blooming of plants from northern Nova Scotia: responses to a mild fall and winter. Proceedings of the Nova Scotian Institute of Science 46: 149-174.

Garbary, D.J., \& Taylor, B.R. (2007) Flowering during January in Antigonish County, Nova Scotia. Canadian Field-Naturalist 121: 76-80.

Grime, J.P. (1979) Plant Strategies and Vegetation Processes. Wiley \& Sons, Chichester. 
Gu, L., Hanson, P.J., Post, W.M., Kaiser, D.P., Yang, B., Nemani, R., Pallardy, S.G., \& Meyers, T. (2008) The 2007 eastern US spring freeze: increased cold damage in a warming world? Bioscience 58: 253-262.

Hill, N.M., \& Blaney, C.S. (2010) Exotic and invasive vascular plants of the Atlantic Maritime Ecozone. In: McAlpine D.F., \& I. M. Smith (eds.), Assessment of Species Diversity in the Atlantic Maritime Ecozone. NRC Research Press, Ottawa, Canada, pp. 215-232.

Houghton, J.T., Ding, Y., Griggs, D.J., Noguer, M., van der Linden, P.J., Dai, X., Maskell, K., \& Johnson, C.A. (2001) Climate Change 2001: The Scientific Basis. Cambridge University Press, Cambridge.

Houle, G. (2007) Spring-flowering herbaceous plant species of the deciduous forests of eastern Canada and $20^{\text {th }}$ century climate warming. Canadian Journal of Forest Research 37: 505-512.

Huston, M.A. (1994) Biological Diversity: The Coexistence of Species on Changing Landscapes. Cambridge University Press, Cambridge.

McCarty, J.P. (2001) Ecological consequences of recent climate change. Conservation Biology 15: 320-331.

Menzel, A. (2003) Plant phenological anomalies in Germany and their relation to air temperature. Climate Change 57: 243-263.

Menzel, A., Estrella, N., \& Testka, A. (2005) Temperature response rates from long-term phenological records. Climate Research 30: 21-28.

Miller-Rushing, A.J., \& Primack, R.B. (2008) Global warming and flowering times in Thoreau's Concord: A community perspective. Ecology 89: 332-341.

Panchen, Z.A., Primack, R.B., Anisko, T., \& Lyons, R.E. (2012) Herbarium specimens, photographs, and field observations show Philadelphia area plants are responding to climate change. American Journal of Botany 99: 751-756.

Roland,A.E. (1998) Roland's Flora of Nova Scotia, $3^{\text {rd }}$ ed. Nimbus Publishing Ltd and Nova Scotia Museum of Natural History, Halifax, Nova Scotia.

Roland,A.E., \& Olson, A.R. (1993) Spring Wildflowers. Nimbus Publishing Ltd. and Nova Scotia Museum of Natural History, Halifax, Nova Scotia.

Taylor, B.R., Ferrier, J., Lauff, R., \& Garbary, D.J. (2008) New distribution records for flowering plants in Antigonish County, Nova Scotia. Proceedings of the Nova Scotian Institute of Science 44: 109-123.

Taylor, B.R., \& Garbary, D.J. (2003) Late-flowering plants from northern Nova Scotia. Rhodora 105: 118-135.

Vasseur, L., Guscott, R.L., \& Mudie, P.J. (2001) Monitoring of spring flower phenology in Nova Scotia: comparison over the last century. Northeastern Naturalist 8: 393-402.

Walther, G.R., Berger, S., \& Sykes, M.T. (2005) An ecological 'footprint' of climate change. Proceedings of the Royal Society of London, Series B, Biological Sciences 272: 1427-1432. 